\title{
Above Ground Drip Application Practices Alter Water Productivity of Malbec Grapevines under Sustained Deficit
}

\author{
Krista C. Shellie ${ }^{1}$ \\ ${ }^{1}$ U.S. Department of Agriculture, Agricultural Research Service, Horticultural Crops Research Unit, Parma, \\ Idaho, USA \\ Correspondence: Krista Shellie, U.S. Department of Agriculture, Agricultural Research Service, 29603 U of I \\ Lane, Parma, ID 83660, USA. Tel: 1-208-722-6701. E-mail: krista.shellie@ars.usda.gov
}

$\begin{array}{ll}\text { Received: March 17, } 2017 & \text { Accepted: April 16, } 2017 \quad \text { Online Published: May 15, } 2017 \\ \text { doi:10.5539/jas.v9n6p1 } & \text { URL: https://doi.org/10.5539/jas.v9n6p1 }\end{array}$

This research was partially financed by a grant from the Northwest Center for Small Fruits Research and the Agricultural Research Service project 5358-21000-034-00D.

\begin{abstract}
An objective of this study was to identify above ground drip application practices for winegrape that increase water productivity and mitigate water deficit-associated loss of yield. The influence of irrigation frequency on water productivity under two severities of sustained deficit irrigation was evaluated in field grown Malbec grapevines (Vitis vinifera L.) over three growing seasons. A weekly amount of water was delivered in a single irrigation event (1X) or apportioned into thirds and delivered in three irrigation events per week (3X). The least severe deficit (STD) had a 3-yr average maximum duty cycle (ratio of irrigation duration to irrigation interval) of 0.3 , and vines irrigated $3 \mathrm{X}$ relative to $1 \mathrm{X}$ had higher water productivity each year due to a decrease in pruning weight. The most severe deficit (STD50) had a 3-yr average maximum duty cycle of 0.02 and vines irrigated $1 \mathrm{X}$ relative to $3 X$ had higher water productivity due to a reduction in pruning weight in 2012 and an increase in yield in 2013. The fruit produced from vines irrigated at the frequency with highest water productivity under each deficit severity contained a lower concentration of anthocyanins. While treatment combinations did not alleviate a water-stress associated reduction in yield, results provided new information about grapevine water use efficiency that can be used to select combinations of irrigation frequencies and duty cycles with potential for increasing water productivity.
\end{abstract}

Keywords: irrigation, Vitis vinifera L., water productivity, water stress, winegrape

\section{Introduction}

A majority of global winegrape (Vitis vinifera L.) production is located in semi-arid regions where sustainability relies upon efficient use of limited water resources (Medrano et al., 2015). In wine-producing regions that experience summer drought, irrigation is commonly used to optimize vine balance and manage fruit quality (Chaves et al., 2010). However, irrigation for crop production will increasingly take place under water scarcity due to climate change and competition for water with industrial and domestic users (Costa, Ortuño, \& Chaves, 2007; Fereres \& Soriano, 2007; Davies, Zhang, Yang, \& Dodd, 2011). Deficit irrigation is the practice of supplying an amount of water to a crop that is a fraction of the crop's estimated water demand $\left(\mathrm{ET}_{\mathrm{c}}\right)$. Deficit irrigation is widely used as a method to sustain crop productivity under water scarcity. Sustained (SDI) and regulated (RDI) deficit irrigation and partial root-zone drying (PRD) are deficit irrigation strategies used in winegrape production to improve water use efficiency (Fereres \& Soriano 2007; Medrano et al., 2015). Water productivity is the amount of marketable product produced per unit of supplied water and it is a measure of water use efficiency at the crop level (Fereres \& Soriano, 2007; Davies et al., 2011; Medrano et al., 2015). The marketable product produced from winegrapes is the harvested fruit so seasonal water productivity in winegrape can be measured as the relationship between the Ravaz index (ratio of yield to pruning weight) and the amount of supplied water (Davies et al., 2011; Shellie, 2014).

A practical difference between SDI and RDI is the fraction of $\mathrm{ET}_{\mathrm{c}}$ supplied during the growing season. The supplied fraction of $\mathrm{ET}_{\mathrm{c}}$ remains constant under $\mathrm{SDI}$, whereas it is altered at particular phenological stages under 
RDI (Shellie, 2014; Munitz, Netzer, \& Schwartz, 2017). A similar level of water productivity can be attained using SDI or RDI; however, reduced water usage is usually associated with a reduction in yield (Davies et al., 2011; Shellie, 2014). The PRD irrigation strategy evolved from studies with potted grapevines where it was observed that water use efficiency could be increased without reducing berry size by alternating the wet and dry portions of the root zone to induce root-to-shoot signaling of abscisic acid (ABA) (Stoll, Loveys, \& Dry, 2000). A consistent response to PRD can be induced under controlled conditions; however, under field conditions, vine response to PRD has frequently been undistinguishable from that of other deficit irrigation strategies and response has been found to vary according to the supplied percentage of $\mathrm{ET}_{\mathrm{c}}$ (Dodd, 2009; Davies et al., 2011; Sadras, 2009; Chaves et al., 2010; Puértolas, Alcobendas, Alarcón, \& Dodd, 2013; Romero et al., 2015).

When above ground drip is used to supply water for irrigation, the drip emitters create a heterogeneous wetting pattern in the vine row beneath the drip line (Goldberg, Rinot, \& Karu, 1971; Davenport, Stevens, \& Whitley, 2008; Bowen, Bogdanoff, Usher, Estergarrd, \& Watson, 2011). The configuration of the drip system, interval between irrigation events and irrigation amount will alter the spatial and temporal distribution of the wetting pattern in the soil profile (Sinai, Zur, \& Haramati, 2007). The ideal irrigation application should recharge the soil profile in minimum time at a maximal application rate that does not cause water logging or runoff at the soil surface. The different drip irrigation application practices used under field conditions in deficit irrigation trials may partially explain the inconsistent results on vine drought response found in the literature (Sadras, 2009). In the few studies that have investigated the influence of irrigation intervals on water productivity under field conditions, results have been confounded by differing amounts of plant available water in the root zone due to different deficit irrigation treatment amounts (Hepner, Bravdo, Loinger, Cohen, \& Tabacman, 1985) or irrigation frequencies with duty cycles, defined as the ratio of irrigation duration to irrigation interval, that caused excessive drainage or aeration stress from water logging at the soil surface (Goldberg et al., 1971; Selles et al., 2004). The objective of this study was to delineate the influences of above ground drip emitter configuration and irrigation event frequency on water productivity, yield components, and berry maturity in field grown Malbec grapevines under two severities of SDI. A practical goal of the study was to identify water-use-efficient, above ground drip application practices that increase water productivity under deficit irrigation by mitigating water deficit-associated loss of yield.

\section{Materials and Methods}

\subsection{Trial Site and Experimental Design}

The study was conducted in an experimental vineyard located at the University of Idaho Parma Research and Extension Center in Parma, ID (lat. 43 $37^{\prime} 7.9716^{\prime \prime} \mathrm{N}$, long. $116^{\circ} 12^{\prime} 54.1^{\prime \prime} \mathrm{W}, 750 \mathrm{~m}$ asl.) during the 2011, 2012 and 2013 growing seasons. The climate at this location was a Köeppen classification of BSk, meaning that plant growth was limited by water availability. Soil texture at the trial site was a sandy loam with an available water-holding capacity of $0.14 \mathrm{~cm} / \mathrm{cm}$ soil. Water for irrigation was sourced from a ground well located at the trial site. The wine grape cultivar Malbec was planted in 2007 on its own roots in rows oriented north to south with a row and vine spacing of $2.4 \mathrm{~m}$ and $1.8 \mathrm{~m}$, respectively. The vines were double-trunked and each trunk was trained to form one side of a bilateral cordon. Canes were spur-pruned annually to $16 \mathrm{buds} / \mathrm{m}$ of cordon. Shoots were vertically positioned on a two-wire trellis with moveable wind wires. Disease, weed and pest control were managed according to local commercial practices.

The experimental design was a $2 \times 3$ factorial, split-split plot with six replicate blocks. Irrigation amount was the main factor. Drip line emitter spacing/delivery rate was split within each irrigation amount. Irrigation event frequency was split within each drip line configuration subplot. A block was comprised of 12 adjacent vine rows with 12 vines per row. Six consecutive vines across the 12 adjacent rows of each block were deficit irrigated from fruitset until harvest with 70 (STD) or 35\% (STD50) of estimated weekly ET $\mathrm{E}_{\mathrm{c}}$. The STD irrigation amount was intended to induce a sustained, mild water deficit, similar to standard industry practice (Keller, Smithyman, \& Mills, 2008). Weekly $\mathrm{ET}_{\mathrm{c}}$ was calculated by multiplying the value for reference crop evapotranspiration $\left(\mathrm{ET}_{\mathrm{r}}\right)$, acquired from a weather station located within $3 \mathrm{~km}$ of the study site (http://www.usbr.gov/pn/agrimet/ wxdata.html), by the value of a crop coefficient that was increased from 0.3 to 0.7 during the growing season (Allen, Pereira, Raes, \& Smith, 1998; Keller et al., 2008). Different spacing between in-line emitters with different delivery rates were used to create spatially different soil wetting patterns. Six adjacent rows within each irrigation subplot had above ground drip with an emitter spacing/delivery rate of $45 \mathrm{~cm} / 16.7 \mathrm{ml} / \mathrm{min}$ or 90 $\mathrm{cm} / 33.4 \mathrm{ml} / \mathrm{min}$. Both emitter spacing/delivery rate configurations delivered the same amount of water per hour. Plots with $45 \mathrm{~cm}$ emitter spacing had four emitters per vine (4E) and plots with $90 \mathrm{~cm}$ emitter spacing had two emitters per vine (2E). Each drip line configuration was used to supply a weekly amount of water as a single weekly event (1X) or apportioned into thirds and delivered as three irrigation events per week (3X). Three 
adjacent rows (6 vines per row) with the same drip emitter configuration were irrigated $1 \mathrm{X}$ or $3 \mathrm{X}$. Vines located in outer rows and at either end of the interior row of each plot were treated as guard vines. Data were collected from vines located in the interior of the middle row of each plot. The trial perimeter had a two-vine deep border. Allocation of irrigation amount, emitter spacing/delivery configuration and irrigation event frequency treatment levels was randomized within each replicate block and the same treatment level was applied to all plots in each successive year of the study. The six replicate blocks for each treatment level were connected to one of eight, independently controlled, water supply manifolds. The manifolds were equipped with a programmable solenoid and a flow meter. All plots were irrigated to field capacity prior to budbreak. There were no subsequent irrigations until the start of treatment applications. The irrigation treatments were initiated after fruitset, when berries were $\sim 7 \mathrm{~mm}$ in diameter and vines were at growth stage 31 of the modified E-L grapevine growth stage system (Coombe, 1995).

\subsection{Soil Moisture and Vine Water Status}

Soil moisture was recorded hourly using a time domain reflectometry (TDR) data-logging system (Moisture Point; Environmental Sensors Inc. Sydney, Canada). Each probe was 91-cm long and had measurement sensors located at soil depths of 30,46,61,76, and $91 \mathrm{~cm}$. One probe was permanently installed at a standard distance from the vine trunk and drip emitter, as described by Bowen, Bogdanoff, and Estergaard (2012), in a single replicate of each subplot.

Vine water status was monitored weekly by measuring leaf water potential at midday $\left(\Psi_{\mathrm{lmd}}\right)$ using a pressure chamber (model 610; PMS Instruments; Corvallis, OR) as described by Shellie (2014). Weekly $\Psi_{\text {Imd }}$ was measured on the sixth day after a weekly irrigation event. In 2013 , the ${ }^{13} \mathrm{C} /{ }^{12} \mathrm{C}$ ratio $\left(\delta^{13} \mathrm{C}\right)$ of juice at harvest was measured following the method of Herrero-Langreo, Tisseyre, Goutouly, Scholasch, and Van Leeuwen (2013).

\subsection{Yield Components and Berry Composition}

Fruit were harvested when a composite sample of randomly collected clusters had a target soluble solids concentration (SS) of $\sim 24 \%$ and a juice titratable acidity (TA) of 4 to $6 \mathrm{~g} / \mathrm{L}$. All plots were harvested on the same day. On the day of harvest, a basal cluster was removed from either side of two main shoots from the center two data vines in each plot $(n=8 /$ plot $)$. The sampled clusters were immediately placed into a cooler and transported to the lab on the day of harvest. The remaining clusters on each data vine were counted as they were removed from the vine and their weight was added to the weight of sampled clusters to determine yield per vine. Sampled clusters were individually weighed and used to calculate average cluster weight. Average berry fresh weight and number of berries per cluster were determined by counting the number of berries per cluster and dividing the weight of the cluster by the number of berries per cluster (2011 and 2012) or by dividing average cluster weight by the average weight of 100 , randomly sampled berries (2013). Samples of 100 berries were stored at $-80{ }^{\circ} \mathrm{C}$ for analysis of total berry anthocyanins following the method of Iland, Bruer, Edwards, Weeks, \& Wilkes (2004), and for $\delta^{13} \mathrm{C}$ analysis by isotope-ratio mass spectrometry at the Stable Isotope Facility (UC Davis, University of California Davis, CA).

The remaining berries from the 8-cluster sample were used to measure juice SS, $\mathrm{pH}$ and TA following methods of Iland et al. (2004) using equipment previously described by Shellie (2006). The same vines harvested for yield and berry measurements were pruned to two bud spurs during dormancy and pruned canes from each vine were weighed. The ratio of yield to pruning weight (Ravaz index) was calculated as an indicator of vine balance. Water productivity was expressed as the relationship between the Ravaz index and seasonal irrigation amount.

Seasonal cumulative growing degree days (GDD) were calculated from daily maximum (no upper limit) and minimum temperatures from $1 \mathrm{Apr}$ to 31 Oct using a base threshold of $10^{\circ} \mathrm{C}$. Temperature data were obtained from the same weather station used for $\mathrm{ET}_{\mathrm{r}}$.

\subsection{Statistical Analysis}

Data were analyzed by year using a mixed model analysis of variance with a $2 \times 3$ factorial and split-split plot treatment structure (SAS version 8.02; SAS Institute, Cary, NC). Fixed effects were irrigation amount, emitter configuration, and irrigation frequency. Weekly $\Psi_{\text {lmd }}$ were analyzed by phenological stage of the vine. Probability of a significant difference among fixed effect treatment levels $(p \leq 0.05)$ was determined using the Tukey-Kramer adjusted t-test. The significance of interaction effects was determined using the LSMEANS slice statement at $\mathrm{p} \leq 0.05$. Graphs presented in figures were generated using Sigmaplot 11.2 (Systat Software, San Jose, CA). 


\section{Results}

\subsection{Environmental Conditions and Irrigation Amounts}

In 2011, seasonal GDD accumulation and $\mathrm{ET}_{\mathrm{r}}$ were lowest of the three study years and were 14 and $7 \%$ lower than the 11-yr average for the location (Table 1). In 2012, GDD and seasonal $\mathrm{ET}_{\mathrm{r}}$ were similar to the 11-yr site average. In 2013, seasonal GDD was similar to the 11-yr site average but $\mathrm{ET}_{\mathrm{r}}$ was $6 \%$ higher than the 11-yr site average. The amount of seasonal precipitation was similar to the $11-\mathrm{yr}$ site average in each study year. The onset of bloom and the day of harvest in 2011 were 20 and 27 days later than in 2013. In 2011, 2012 and 2013 the day of year for bloom was 175, 167, and 155; for veraison was 241, 233 and 224; and for harvest was 293, 284 and 266, respectively. The elapsed number of days between bloom and veraison was 66 (2011 and 2012) and 69 (2013); and between veraison and harvest was 51 (2011 and 2012) and 42 (2013).

Irrigation treatments were initiated on day of year 173, 179 and 184 and were applied for 15, 14 and 12 weeks in 2011, 2012 and 2013, respectively. The amount of water supplied to vines under the STD irrigation amount was 37,45 and $35 \%$ of seasonal $\mathrm{ET}_{\mathrm{r}}$ in 2011, 2012 and 2013, respectively (Table 1). Vines under the STD50 irrigation amount were supplied 50 (2011), 43 (2012) and 50\% (2013) of the STD irrigation amount. The amount of water actually delivered to $3 \mathrm{X}$ plots was from 2 to $7 \%$ less than $1 \mathrm{X}$ plots. The amount of water delivered to plots with $4 \mathrm{E}$ drip line configuration was $\sim 1$ to $5 \%$ less than plots with $2 \mathrm{E}$ drip line configuration.

Table 1. Growing season (1 Apr through 31 Oct) environmental conditions at the field trial site and irrigation treatment amounts

\begin{tabular}{lllll}
\hline & 2011 & 2012 & 2013 & $2000-2010$ Average $^{\mathrm{a}}$ \\
\hline $\mathrm{GDD}^{\mathrm{b}}\left({ }^{\circ} \mathrm{C}\right)$ & 1488 & 1710 & 1757 & $1733 \pm 162$ \\
$\mathrm{Pcp}^{\mathrm{b}}(\mathrm{mm})$ & 105 & 76 & 102 & $95 \pm 33$ \\
$\mathrm{ET}_{\mathrm{r}}^{\mathrm{b}}(\mathrm{mm})$ & 1155 & 1270 & 1321 & $1243 \pm 46$ \\
\hline Seasonal irrigation treatment amount $(\mathrm{mm})^{\mathrm{c}}$ & & & \\
$\mathrm{STD}$ & 423 & 571 & 468 & \\
$1 \mathrm{X}$ & 439 & 579 & 472 & \\
$3 \mathrm{X}$ & 407 & 562 & 464 & \\
$2 \mathrm{E}$ & 434 & 574 & 475 & \\
$4 \mathrm{E}$ & 411 & 567 & 461 & \\
$\mathrm{STD} 50$ & 210 & 244 & 234 & \\
$1 \mathrm{X}$ & 214 & 251 & 238 & \\
$3 \mathrm{X}$ & 206 & 237 & 231 & \\
$2 \mathrm{E}$ & 215 & 245 & 235 & \\
$4 \mathrm{E}$ & 205 & 243 & 233 & \\
\hline
\end{tabular}

Note. ${ }^{a}$ Average and standard deviation for years 2000 through 2010. ${ }^{b}$ Heat unit accumulation (GDD), precipitation $(\mathrm{Pcp})$ and reference evapotranspiration $\left(\mathrm{ET}_{\mathrm{r}}\right)$ from the Bureau of Reclamation AgriMet system [(www.usbr.gov/pn/grimet/), latitude $43^{\circ} 48^{\prime} 00^{\prime \prime}$, longitude $116^{\circ} 56^{\prime} 00^{\prime \prime}$, elevation $700 \mathrm{~m}$ ] PMAI weather station. GDD calculated as simple average with no upper limit and a base threshold of $10{ }^{\circ} \mathrm{C} . \mathrm{ET}_{\mathrm{r}}$ from 1982 Kimberly-Penman equation for well-watered alfalfa with $30-50 \mathrm{~cm}$ top growth (Jensen et al., 1990). ${ }^{\mathrm{c}}$ Amount of water supplied to Malbec grapevines to satisfy 70 (STD) or 35 (STD50) percent of estimated water demand. Weekly estimated irrigation amount was delivered in a single weekly event (1X) or apportioned into thirds and delivered as three events per week (3X) using above ground drip with in-line emitter spacing/delivery rate configurations of $45 \mathrm{~cm} / 16.7 \mathrm{ml} / \mathrm{min}(4 \mathrm{E})$ or $90 \mathrm{~cm} / 33.4 \mathrm{ml} / \mathrm{min}(2 \mathrm{E})$.

\subsection{Soil Moisture}

Irrigation amount, drip line configuration and irrigation event frequency influenced the vertical depth of water penetration after an irrigation event. Water penetration was deeper under STD $(72$ to $91 \mathrm{~cm})$ than under STD50 (46 to $61 \mathrm{~cm}$ ) and deeper in plots with $2 \mathrm{E}$ than $4 \mathrm{E}$ drip configuration. The average depth of water penetration in plots under STD with 2E drip configuration was $91 \mathrm{~cm}$ when irrigated $1 \mathrm{X}$ and $76 \mathrm{~cm}$ when irrigated $3 \mathrm{X}$. Plots under STD50 with 2E drip configuration had an average depth of water penetration of $61 \mathrm{~cm}$ when irrigated 1X and $46 \mathrm{~cm}$ when irrigated $3 \mathrm{X}$. In plots with 4E drip configuration, the average depth of water penetration was 76 $\mathrm{cm}$ under STD and $46 \mathrm{~cm}$ under STD50, and was similar when irrigated $1 \mathrm{X}$ or $3 \mathrm{X}$. 


\subsection{Leaf Water Potential and ${ }^{\delta} 13 C$}

Weekly $\Psi_{\text {lmd }}$ was measured eight (2011 and 2012) or six (2013) times between fruitset and veraison and five times (all years) between veraison and harvest. The influence of irrigation event frequency on $\Psi_{\text {Imd }}$ was different under each irrigation treatment amount (Figure 1). Under STD, vines irrigated $3 X$ had significantly less negative $\Psi_{\text {lmd }}$ than vines irrigated $1 X$, during the period from fruitset to veraison in 2011 and 2012, and during the period from veraison to harvest in 2012 and 2013. In all three years, the $\Psi_{\mathrm{lmd}}$ of vines under STD50 irrigated 3X was similar, during the period from fruitset to veraison, and significantly different, during the period from veraison to harvest, as vines irrigated $1 \mathrm{X}$. In 2013, irrigation frequency had no influence on $\delta^{13} \mathrm{C}$; however, vines under STD50 had a lower $\delta^{13} \mathrm{C}(-24.13)$ than vines under STD irrigation (-26.65). Emitter configuration had no significant influence on $\Psi_{\text {lmd }}$.
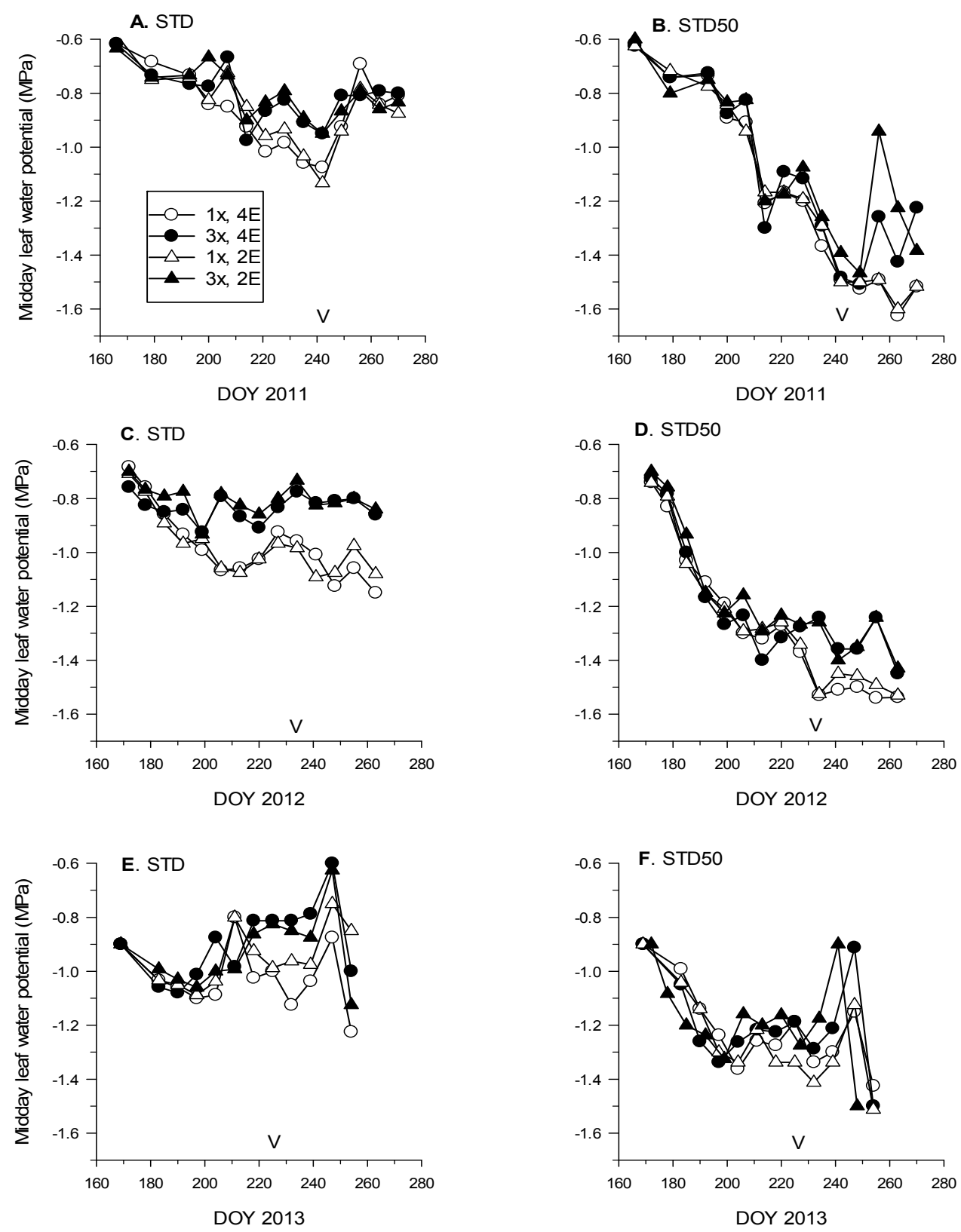

Figure 1. Weekly midday leaf water potential of Malbec grapevines under sustained deficit irrigation that were

supplied 70 (STD) or 35 (STD50)\% of estimated vine water demand as a single weekly event (1X) or apportioned into thirds and applied as three events per week (3X) and delivered with above drip that had an emitter spacing/delivery rate of $45 \mathrm{~cm} / 16.7 \mathrm{ml} / \mathrm{min}$ (4E) or $90 \mathrm{~cm} / 33.4 \mathrm{ml} / \mathrm{min}$ (2E) in 2011 (A and B), 2012 (C and D), and 2013 (E and F). The day of veraison is indicated with the letter "V" 


\subsection{Vine Balance and Water Productivity}

There was a significant interaction between irrigation frequency and irrigation amount on pruning weight each year and on yield in one out of two years (Figure 2). In each respective year, vines under STD irrigated 3X had 19,11 , and $16 \%$ lower pruning weight than vines irrigated $1 \mathrm{X}$. The only year that irrigation frequency had a significant influence on yield under STD was in 2012, when vines under STD irrigated 3X had 21\% higher yield than vines irrigated $1 X$ (Figure 2). In 2012, the berry fresh weight of vines under STD irrigated 3X was greater than that of vines irrigated $1 X$ (Table 2). Vines under STD irrigated 3X had greater cluster weight in 2011 and 2013 and lower berry weight in 2011 than vines irrigated 1X (Table 2); however, these differences had no detectable influence on yield in 2011 or 2013 (Figure 2).

Under STD50, irrigation frequency influenced pruning weight only in 2012 when vines irrigated 1X had 24\% lower pruning weight than vines irrigated 3X (Figure 2). In 2013, vines under STD50 irrigated 1X had higher yield than vines irrigated 3X. In 2013, vines under STD50 irrigated 1X had greater cluster weight and a greater number of berries per cluster than vines irrigated $3 X$ (Table 2).

The dormant pruning weight of vines under STD50 was 34 (2011) or 50\% (2012 and 2013) less than that of vines under STD (Figure 2). Vines under STD50 had 43 and 31\% lower yield than vines under STD in 2012 and 2013, respectively, and similar (5.5 kg) yield per vine in 2011 (Figure 2). In 2012 and 2013, vines under STD50 had $\sim 26 \%$ fewer clusters than vines under STD (Table 2). Vines under STD50 had lower cluster weight and berry fresh weight than vines under STD in each respective year of the study; although the difference in cluster weight in 2013 was not of statistical significance. Drip line configuration had no consistent main or interactive effect on pruning weight or yield (data not shown) or yield components (Table 2).

Table 2. Yield components for Malbec grapevines supplied with 70 (STD) or 35 (STD50) percent of estimated weekly water demand in a weekly event (1X) or apportioned into three events per week (3X) using above ground drip tubing with emitter spacing/delivery rate configurations of $90 \mathrm{~cm} / 33.4 \mathrm{ml} / \mathrm{min}$. (2E) or $45 \mathrm{~cm} / 16.7 \mathrm{ml} / \mathrm{min}$ (4E) over three growing seasons in Parma, ID

\begin{tabular}{|c|c|c|c|c|c|c|c|c|c|c|c|c|}
\hline \multirow{2}{*}{ Treatment } & \multicolumn{3}{|c|}{ Cluster number per vine } & \multicolumn{3}{|c|}{ Cluster weight (g) } & \multicolumn{3}{|c|}{ Berry weight (g) } & \multicolumn{3}{|c|}{ Berry number per cluster } \\
\hline & 2011 & 2012 & 2013 & 2011 & 2012 & 2013 & 2011 & 2012 & 2013 & 2011 & 2012 & 2013 \\
\hline \multicolumn{13}{|l|}{$I^{a}$} \\
\hline STD & 33 & $41 \mathrm{a}$ & $42 \mathrm{a}$ & $180.3 \mathrm{a}$ & $152.7 \mathrm{a}$ & 134.8 & $2.0 \mathrm{a}$ & $1.6 \mathrm{a}$ & $1.4 \mathrm{a}$ & 68 & 87 & 94 \\
\hline STD50 & 36 & $30 \mathrm{~b}$ & $32 b$ & $147.8 \mathrm{~b}$ & $115.5 b$ & 118.0 & $1.7 \mathrm{~b}$ & $1.3 \mathrm{~b}$ & $1.2 \mathrm{~b}$ & 73 & 99 & 101 \\
\hline \multicolumn{13}{|l|}{$I^{*} F^{b^{2}}$} \\
\hline STD-1X & 35 & 41 & 43 & $163.2 \mathrm{a}$ & 148.1 & $127.0 \mathrm{a}$ & $2.2 \mathrm{a}$ & $1.6 \mathrm{a}$ & 1.4 & 69 & 84 & $90 \mathrm{a}$ \\
\hline STD-3X & 30 & 40 & 41 & $197.4 \mathrm{~b}$ & 157.2 & $142.8 b$ & $1.9 \mathrm{~b}$ & $1.7 \mathrm{~b}$ & 1.4 & 66 & 90 & $99 \mathrm{a}$ \\
\hline STD50-1X & 35 & 31 & 31 & $145.6 \mathrm{a}$ & 119.6 & $130.8 \mathrm{a}$ & $1.7 \mathrm{a}$ & $1.3 \mathrm{a}$ & 1.2 & 74 & 91 & $110 \mathrm{a}$ \\
\hline STD50-3X & 36 & 28 & 34 & $150.0 \mathrm{a}$ & 111.4 & $105.3 \mathrm{~b}$ & $1.8 \mathrm{a}$ & $1.3 \mathrm{a}$ & 1.1 & 73 & 107 & $93 b$ \\
\hline \multicolumn{13}{|l|}{ pvalue } \\
\hline Irrigation (I) & $\mathrm{ns}$ & $* *$ & $* *$ & $* *$ & $* *$ & $\mathrm{~ns}$ & $* *$ & $* *$ & $* *$ & ns & $\mathrm{ns}$ & ns \\
\hline Emitter (E) & $\mathrm{ns}$ & $\mathrm{ns}$ & $\mathrm{ns}$ & $\mathrm{ns}$ & $\mathrm{ns}$ & $\mathrm{ns}$ & $\mathrm{ns}$ & $\mathrm{ns}$ & $\mathrm{ns}$ & $\mathrm{ns}$ & $\mathrm{ns}$ & $\mathrm{ns}$ \\
\hline $\mathrm{I} \times \mathrm{E}$ & ns & ns & ns & ns & ns & ns & ns & ns & $\mathrm{ns}$ & $\mathrm{ns}$ & $\mathrm{ns}$ & $\mathrm{ns}$ \\
\hline Frequency (F) & $\mathrm{ns}$ & ns & ns & $\mathrm{ns}$ & $\mathrm{ns}$ & $\mathrm{ns}$ & $\mathrm{ns}$ & $\mathrm{ns}$ & ns & $\mathrm{ns}$ & $\mathrm{ns}$ & $\mathrm{ns}$ \\
\hline $\mathrm{I} \times \mathrm{F}$ & $\mathrm{ns}$ & ns & ns & $*$ & ns & $* *$ & $*$ & $*$ & $\mathrm{~ns}$ & $\mathrm{~ns}$ & $\mathrm{~ns}$ & $* *$ \\
\hline $\mathrm{E} \times \mathrm{F}$ & ns & ns & ns & ns & ns & ns & $\mathrm{ns}$ & $\mathrm{ns}$ & $\mathrm{ns}$ & ns & ns & ns \\
\hline $\mathrm{I} \times \mathrm{E} \times \mathrm{F}$ & $\mathrm{ns}$ & ns & ns & ns & ns & $\mathrm{ns}$ & $\mathrm{ns}$ & $\mathrm{ns}$ & $* *$ & $\mathrm{~ns}$ & $\mathrm{~ns}$ & $\mathrm{~ns}$ \\
\hline
\end{tabular}

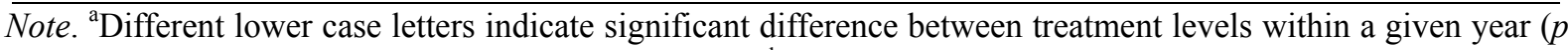
$\leq 0.05$ determined by Tukey-Kramer adjusted t-test). ${ }^{b}$ Least square mean values followed by a different letter between subplot treatment level rows within a year column are significantly different $(p \leq 0.05)$ according to LSMEANS slice statement using a mixed model analysis of variance. ${ }^{c *}, p \leq 0.05 ; * *, p \leq 0.01$; ns, not significant. 

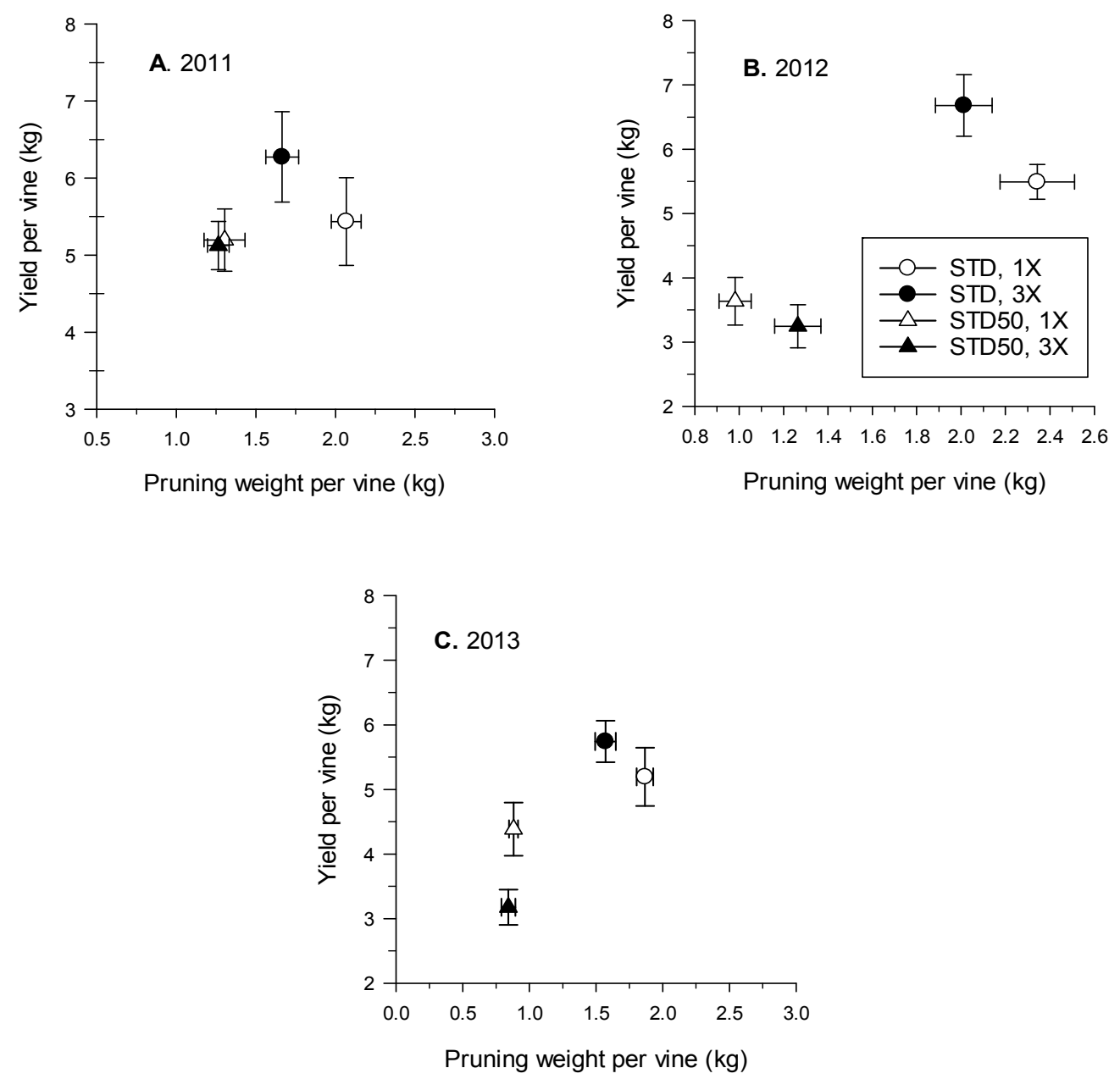

Figure 2. Relationship between pruning weight and yield in Malbec grapevines under sustained deficit irrigation that supplied 70 (STD) or 35 (STD50)\% of estimated vine water demand as a single weekly event (1X) or apportioned into thirds and applied as three events per week (3X). Error bars represent the standard error of the mean

Irrigation frequency had a significant influence on the Ravaz index and the effect differed by irrigation amount (Figure 3). More frequent irrigation significantly increased the Ravaz index of vines under STD in all years, but decreased the Ravaz index of vines under STD50 in two out of three years. Vines under STD irrigated 3X had a higher Ravaz index than that of vines irrigated $1 \mathrm{X}$ by 37,31 and $26 \%$ in each respective year. Vines under STD50 irrigated 3X had a lower Ravaz index than vines irrigated $1 \mathrm{X}$ by 28 and $23 \%$ in 2012 and 2013, respectively. Irrigation amount had no significant effect on the Ravaz index in 2011 or 2012. In 2013 the Ravaz index was significantly higher in vines under STD50 (4.6) than in vines under STD (3.4). In 2011 and 2012, the Ravaz index was 3.9 and 3.2, respectively. Drip line configuration had no consistent influence on the Ravaz index. 

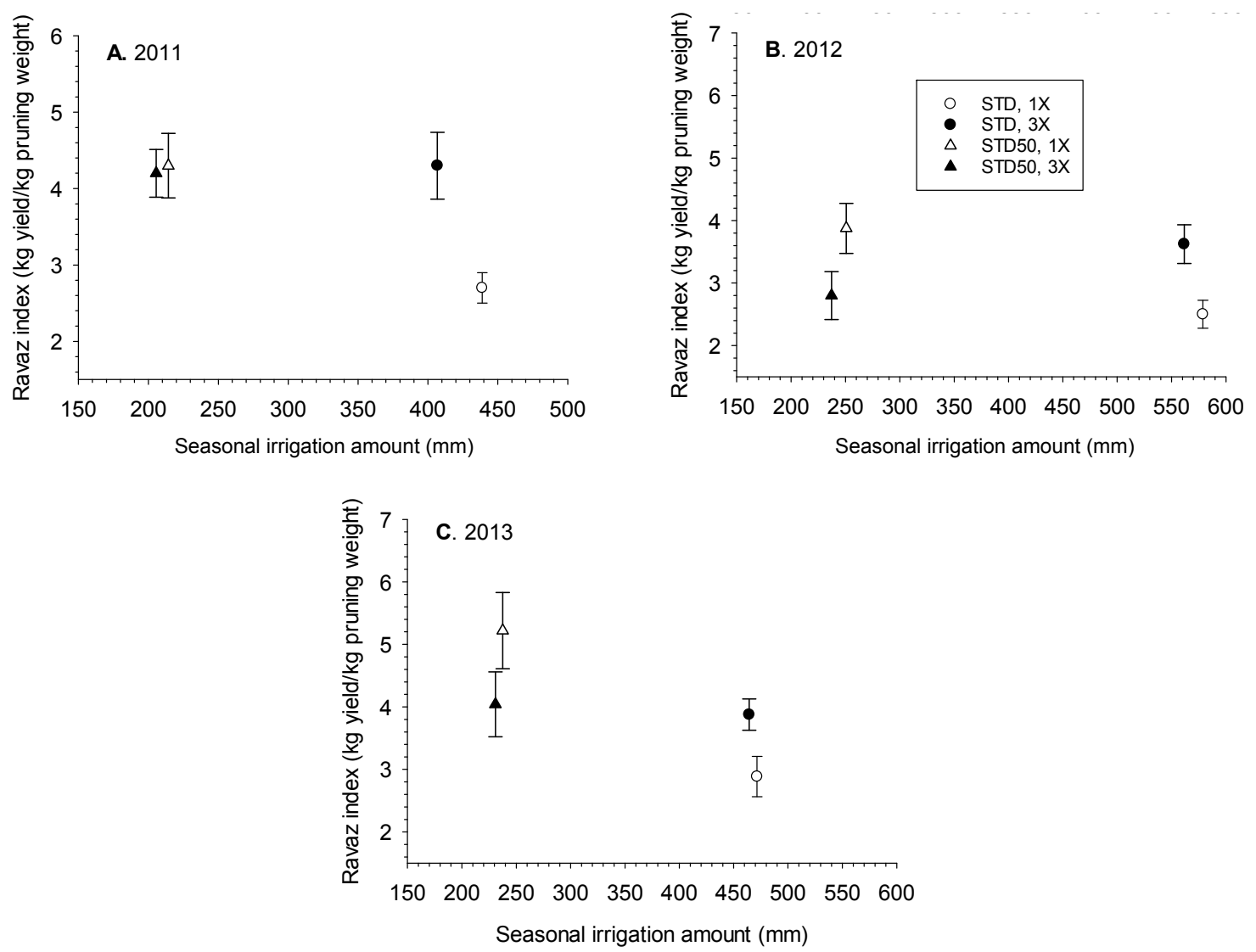

Figure 3. Water productivity of Malbec grapevines under sustained deficit irrigation that supplied 70 (STD) or 35 (STD50)\% of estimated vine water demand as a single weekly event (1X) or apportioned into thirds and applied as three events per week (3X). Error bars represent the standard error of the mean

\subsection{Berry Composition}

The SS and $\mathrm{pH}$ of juice at harvest were similar among all treatments (data not shown). In each respective year, SS was 23,25 , and $22 \%$ at the time of harvest; and $\mathrm{pH}$ was $4.0,3.9$, and 3.7. Irrigation event frequency and drip emitter configuration had no consistent main or interactive effects on juice TA; however, the TA of juice from vines under STD50 was lower each year than vines under STD (Table 3).

The influence of irrigation event frequency on the concentration of anthocyanins and phenolics was inconsistent among years and differed by irrigation amount (Table 3). In vines under STD, the concentration of anthocyanins in berries irrigated 3X was lower in 2011 and 2012 than that of vines irrigated 1X. The concentration of phenolics in vines under STD irrigated 3X was similar in 2011 and 2013 and lower in 2012 than vines irrigated 1X. Under STD50, the concentration of anthocyanins and phenolics in berries from vines irrigated $3 \mathrm{x}$ was higher than that of vines irrigated $1 \mathrm{X}$ in each year of the study, though the difference in anthocyanins was not of statistical significance in 2012. Berries from vines under STD50 had a higher concentration of anthocyanins and phenolics in 2012 and 2013 than that of vines under STD (Table 3). 
Table 3. Berry composition of Malbec grapevine at fruit maturity. Vines were supplied with 70 (STD) or 35 (STD50) percent of estimated weekly water demand as a single weekly irrigation event (1X) or apportioned into three events per week (3X) and delivered using above ground drip tubing with emitter spacing/delivery rate configurations of $90 \mathrm{~cm} / 33.4 \mathrm{ml} / \mathrm{min}$. (2E) or $45 \mathrm{~cm} / 16.7 \mathrm{ml} / \mathrm{min}$ (4E) over three growing seasons in Parma, ID

\begin{tabular}{|c|c|c|c|c|c|c|c|c|c|}
\hline & \multicolumn{3}{|c|}{ Titratable acidity } & \multicolumn{3}{|c|}{ Total anthocyanins } & \multicolumn{3}{|c|}{ Total phenolics } \\
\hline & 2011 & 2012 & 2013 & 2011 & 2012 & 2013 & 2011 & 2012 & 2013 \\
\hline & \multicolumn{3}{|c|}{-------------- g/L ------------- } & \multicolumn{3}{|c|}{--- mg/g berry fresh weight --- } & \multicolumn{3}{|c|}{-- mg/g berry fresh weight -- } \\
\hline \multicolumn{10}{|l|}{ Irrigation $(I)^{a}$} \\
\hline STD & $9.41 \mathrm{a}$ & $7.02 \mathrm{a}$ & $6.26 \mathrm{a}$ & 1.92 & $2.01 \mathrm{a}$ & $1.65 \mathrm{a}$ & 1.42 & $1.44 \mathrm{a}$ & $1.59 \mathrm{a}$ \\
\hline STD50 & $6.35 b$ & $4.82 b$ & $5.07 \mathrm{~b}$ & 1.92 & $2.24 b$ & $1.86 \mathrm{~b}$ & 1.46 & $1.65 b$ & $1.82 b$ \\
\hline \multicolumn{10}{|l|}{$I^{*}$ Frequency } \\
\hline STD-1X & 9.47 & 7.17 & $6.49 \mathrm{a}$ & $1.98 \mathrm{a}$ & $2.12 \mathrm{a}$ & $1.53 \mathrm{a}$ & $1.41 \mathrm{a}$ & $1.50 \mathrm{a}$ & $1.58 \mathrm{a}$ \\
\hline STD-3X & 9.36 & 6.87 & $6.03 b$ & $1.87 \mathrm{~b}$ & $1.89 \mathrm{~b}$ & $1.77 \mathrm{a}$ & $1.42 \mathrm{a}$ & $1.38 \mathrm{~b}$ & $1.60 \mathrm{a}$ \\
\hline STD50-1X & 6.17 & 4.94 & $4.86 \mathrm{a}$ & $1.85 \mathrm{a}$ & $2.22 \mathrm{a}$ & $1.79 \mathrm{a}$ & $1.43 \mathrm{a}$ & $1.63 \mathrm{a}$ & $1.75 \mathrm{a}$ \\
\hline STD50-3X & 6.53 & 4.71 & $5.28 \mathrm{a}$ & $1.99 \mathrm{~b}$ & $2.27 \mathrm{a}$ & $1.92 \mathrm{~b}$ & $1.49 \mathrm{~b}$ & $1.68 \mathrm{~b}$ & $1.89 \mathrm{~b}$ \\
\hline \multicolumn{10}{|l|}{ p value } \\
\hline Irrigation (I) & $* *$ & $* *$ & $* *$ & ns & $* *$ & $* *$ & ns & $* *$ & $* *$ \\
\hline Emitter (E) & ns & ns & ns & $* *$ & ns & ns & ns & ns & ns \\
\hline $\mathrm{I} \times \mathrm{E}$ & ns & ns & ns & $* *$ & ns & ns & $*$ & ns & ns \\
\hline Frequency & ns & ns & ns & ns & $\mathrm{ns}$ & ns & ns & $* *$ & $*$ \\
\hline $\mathrm{I} \times \mathrm{F}$ & ns & ns & $*$ & $* *$ & $* *$ & $*$ & $* *$ & $* *$ & $* *$ \\
\hline $\mathrm{E} \times \mathrm{F}$ & ns & ns & $*$ & ns & $* *$ & ns & ns & $* *$ & ns \\
\hline $\mathrm{I} \times \mathrm{E} \times \mathrm{F}$ & ns & ns & ns & $* *$ & $* *$ & ns & $* *$ & $* *$ & $* *$ \\
\hline
\end{tabular}

Note. ${ }^{\text {a }}$ Different lower case letters indicate significant difference between main effect treatment levels within a given year ( $p \leq 0.05$ determined by Tukey-Kramer adjusted t-test). ${ }^{\mathrm{b}}$ Least square mean values followed by a different letter between subplot treatment level rows within a year column are significantly different $(p \leq 0.05)$ according to LSMEANS slice statement in mixed model analysis of variance. ${ }^{c *}, p \leq 0.05 ;{ }^{* *}, p \leq 0.01$; ns, not significant.

\section{Discussion}

A practical goal of this study was to identify water use efficient, above ground drip application practices that mitigate undesirable, water deficit-associated loss of yield in winegrape. The irrigation event intervals evaluated in this study under each severity of deficit irrigation alleviated water stress-associated yield reduction in only one out of three years; however, the observed interaction between irrigation amount and event frequency on water productivity provides new information about irrigation frequency and duty cycle combinations that influence water productivity under SDI.

In this study, irrigation amount and event frequency influenced the vertical depth of moisture in the soil profile. The distribution of soil moisture under drip irrigation has been described as mainly two dimensional, with soil moisture content highest beneath the drip line and decreasing laterally (Goldberg et al., 1971; Selles et al., 2004; Davenport et al., 2008; Bowen et al., 2012). A model using irrigation frequency and irrigation duty cycle, defined as the ratio of irrigation duration to irrigation interval, was used by Sinai et al. (2007) to predict maximum depth of water penetration under drip irrigation. Depth of water penetration was shown to increase with less frequent irrigation or with increasing duty cycle values (Sinai et al., 2007). In this study, plots irrigated $1 \mathrm{X}$ and $3 \mathrm{X}$ under each irrigation amount had similar duty cycle values. The 3-yr average maximum duty cycle value under STD was 0.30 and under STD50 was 0.02. The different duty cycle values for STD and STD50 and different irrigation frequency in $1 \mathrm{X}$ and $3 \mathrm{X}$ plots explain the greater depth of water penetration observed under STD relative to $\mathrm{STD} 50$ and in plots irrigated $1 \mathrm{X}$ relative to $3 \mathrm{X}$.

The author found three published field studies with winegrapes in which above ground drip irrigation interval was evaluated as a treatment (Goldberg et al., 1971; Hepner et al., 1985; Selles et al., 2004). In the study of Hepner et al. (1985), the main effect of irrigation frequency could not be evaluated because it was confounded within different severities of SDI and RDI. In Goldberg et al. (1971) and Selles et al. (2004), an amount of water equal to estimated demand (well-watered) was delivered at irrigation frequencies similar to the $1 \mathrm{X}$ and $3 \mathrm{X}$ 
frequencies evaluated in this study. In both of these studies, depth of water penetration increased with less frequent irrigation. Goldberg et al. (1971) and Selles et al. (2004) found that irrigation frequency influenced water productivity and that higher productivity was due to an increase in yield that was proportionally greater than the increase in pruning weight. Goldberg et al. (1971) found that water productivity increased as irrigation frequency increased, whereas Selles et al. (2004) reported an inverse relationship between water productivity and irrigation frequency. The contrasting results of these two studies could be due to different soil textures and/or the amount of supplied water relative to actual vine water demand.

The influence of irrigation frequency on water productivity in this study differed according to deficit irrigation amount. An interaction between irrigation amount and application timing on drought response has also been noted by Romero et al. (2015). Under the least severe water deficit (STD), more frequent irrigation increased water productivity each year and the increase was due to a decrease in pruning weight. An explanation for the reduction in pruning weight of vines under STD irrigated $3 \mathrm{X}$ is not readily apparent from $\Psi_{\mathrm{lmd}}$ values. Reduction of shoot growth is usually associated with a $\Psi_{\mathrm{Imd}}$ value $\leq-1.0 \mathrm{MPa}$ (Shellie, 2006). However, in this study, vines under STD irrigated 3X had values of $\Psi_{\operatorname{lmd}}$ more negative than -1.0 MPa only in 2013. Under STD, the fruit produced from plots with highest water productivity had a lower concentration of anthocyanins in 2011 and 2012 The lower concentration of anthocyanins could be attributed to the higher values of $\Psi_{\text {lmd }}$ between fruitset and veraison in $3 \mathrm{X}$ relative to $1 \mathrm{X}$ irrigated plots.

Under the most severe water deficit (STD50), less frequent irrigation was associated with increased water productivity in 2012 and 2013. The increase in 2012 was due to a decrease in pruning weight and the increase in 2013 was due to an increase in yield. The decrease in pruning weight in 2012 was most likely due to the more negative $\Psi_{\mathrm{lmd}}$ of vines irrigated $1 \mathrm{X}$ relative to $3 \mathrm{X}$. The greater number of berries per cluster observed in $1 \mathrm{X}$ plots under STD50 in 2013 might have been related to the less negative $\Psi_{\text {Imd }}$ in the first weeks after fruitset which could have reduced the amount of water stress-associated berry abscission (May, 2004). Under STD50, the irrigation frequency with highest water productivity had the lowest concentrations of anthocyanins and phenolics. This lower concentration was not due to a lack of vine water stress, as vines irrigated $1 \mathrm{X}$ had lower $\Psi_{\mathrm{Imd}}$ than vines irrigated 3X. The concentration of phenolics may have been lower in vines under STD50 irrigated 1x relative to $3 \mathrm{X}$ because of more frequent exposure to high temperatures. An increase in canopy temperature under deficit irrigation has been associated with lower anthocyanin accumulation (Shellie \& King, 2013). The cumulative duration of exposure to damaging high temperatures may have been greater under $1 \mathrm{X}$ than $3 \mathrm{X}$ due to the longer interval between irrigation events.

Under each irrigation amount, increased water productivity was accompanied by an increase in yield in only one out of three years. An increase in yield and decrease in pruning weight occurred only under STD in 2012 in plots irrigated 3X. This was also the only year when a significant difference in $\Psi_{\mathrm{Imd}}$ was maintained throughout berry development between vines irrigated $1 X$ and 3X. The increase in berry fresh weight in 2012 in vines under STD irrigated $3 \mathrm{X}$ was likely attributed to higher vine water status. The general lack of yield response to the irrigation frequencies and duty cycles evaluated in this study suggests that the pattern of soil moisture distribution associated with the treatment combinations evaluated in this study did not induce the same drought response observed in potted vines under partial root-zone drying (Stoll et al., 2000; Sadras, 2009).

The influence of deficit irrigation severity on yield components, berry maturity and berry composition observed in this study were similar to that reported by others (Shellie, 2006; Shellie, 2014; Romero et al., 2015; Munitz et al., 2017). The irrigation intervals evaluated in this study did not alleviate a water-stress associated reduction in yield under either severity of deficit irrigation; however, study results provide new information about water use efficiency that can be used to identify combinations of irrigation frequencies and duty cycles with potential for increasing water productivity.

\section{Acknowledgements}

This research was partially funded by a grant from the Northwest Center for Small Fruits Research and the Agricultural Research Service project 5358-21000-034-00D. The author thanks Alan Muir and Monte Shields for their technical assistance and the University of Idaho Parma Research and Extension Center for the use of their field resources and materials.

\section{References}

Allen, R. G., Pereira, L. S., Raes, D., \& Smith, M. (1998). Crop evapotranspiration-guidelines for computing crop water requirements-FAO Irrigation and drainage paper 56. Rome, Italy: Food Agricultural Organization (FAO). 
Bowen, P., Bogdanoff, C., Usher, K., Estergaard, B., \& Watson, M. (2011). Effects of irrigation and crop load on leaf gas exchange and fruit composition in red winegrapes grown on aloamy sand. American Journal of Enology and Viticulture, 62, 9-22. https://doi.org/10.5344/ajev.2010.10046

Bowen, P., Bogdanoff, C., \& Estergaard, B. (2012). Effects of converting from sprinkler to drip irrigation on water conservation and the performance of Merlot grown on a loamy sand. American Journal of Enology and Viticulture, 63, 385-393. https://doi.org/10.5344/ajev.2012.12002

Chaves, M. M., Francisco, Z. R., Costa, J. M., Santos, T., Regalado, A. P., Rodrigues, M. L., \& Lopes, C. M. (2010). Grapevine under deficit irrigation: hints from physiological and molecular data. Annals of Botany, 105, 661-676. https://doi.org/10.1093/aob/mcq030

Coombe, B. G. (1995). Growth stages of the grapevine: Adoption of a system for identifying grapevine growth stages. Australian Journal of Grape and Wine Research, 1, 104-110. https://doi.org/10.1111/j.1755-0238. 1995.tb00086.x

Costa, J. M., Ortuño, M. F., \& Chaves, M. M. (2007). Deficit irrigation as a strategy to save water: Physiology and potential application to horticulture. Journal of Integrated Plant Biology, 49, 1421-1434. https://doi.org/10.1111/j.1672-9072.2007.00556.x

Davenport, J. R., Stevens, R. G., \& Whitley, K. M. (2008). Spatial and temporal distribution of soil moisture in drip-irrigated vineyards. HortScience, 43, 229-235.

Davies, W. J., Zhang, J., Yang, J., \& Dodd, I. C. (2011). Novel crop science to improve yield and resource use efficiency in water-limited agriculture. Journal of Agricultural Science, 149, 123-131. https://doi.org/ $10.1017 / \mathrm{S} 0021859610001115$

Dodd, I. C. (2009). Rhizosphere manipulations to maximize 'crop per drop' during deficit irrigation. Journal of Experimental Botany, 60, 2454-2459. https://doi.org/10.1093/jxb/erp192

Fereres, E., \& Soriano, M. A. (2007). Deficit irrigation for reducing agricultural water use. Journal of Experimental Botany, 58, 147-159. https://doi.org/10.1093/jxb/erl165

Goldberg, S. D., Rinot, M., \& Karu, N. (1971). Effect of trickle irrigation intervals on distribution and utilization of soil moisture in a vineyard. Soil Science Society of America, Proceedings, 35, 127-130. https://doi.org/10.2136/sssaj1971.03615995003500010037x

Hepner, Y., Bravdo, B., Loinger, C., Cohen, S., \& Tabacman, H. (1985). Effect of drip irrigation schedules on growth, yield, must composition and wine quality of Cabernet Sauvignon. American Journal of Enology and Viticulture, 36, 77-85.

Herrero-Langreo, A., Tisseyre, B., Goutouly, J., Scholasch, T., \& Van Leeuwen, C. (2013). Mapping grapevine (Vitis vinifera L.) water status during the season using carbon isotope ratio $\left(\delta^{13} \mathrm{C}\right)$ as ancillary data. American Journal of Enology and Viticulture, 64, 307-315. https://doi.org/10.5344/ajev.2013.12125

Iland, P., Bruer, N., Edwards, G., Weeks, S., \& Wilkes, E. (2004). Chemical analysis of grapes and wine: Techniques and concepts (2nd ed.). Campbelltown, Australia: Patrick Iland.

Keller, M., Smithyman, R. P., \& Mills, L. J. (2008). Interactive effects of deficit irrigation and crop load on Cabernet Sauvignon in an arid climate. American Journal of Enology and Viticulture, 59, 221-234.

May, P. (2004). Flowering and fruitset in grapevines. Adelaide, South Australia: Lythrum Press.

Medrano, H., Tomás, M., Martorell, S., Escalona, J., Pou, A., Fuentes, S., ... Bota, B. (2015). Improving water use efficiency of vineyards in semi-arid regions: A review. Agronomy for Sustainable Development, 35, 499-517. https://doi.org/10.1007/s13593-014-0280-z

Munitz, S., Netzer, Y., \& Schwartz, A. (2017). Sustained and regulated deficit irrigation of field-grown Merlot grapevines. Australian Journal of Grape and Wine Research, 23, 87-94. https://doi.org/10.1111/ajgw.12241

Romero, P., Muñoz, R. G., Fernándex-Fernándex, J. I., del Amor, F. M., Martínez-Cutillas, A., \& García-García, J. (2015). Improvement of yield and grape and wine composition in field-grown Monastrell grapevines by partial root zone irrigation, in comparison with regulated deficit irrigation. Agricultural Water Management, 149, 55-73. https://doi.org/10.1016/j.agwat.2014.10.018

Sadras, V. O. (2009). Does partial root-zone drying improve irrigation water productivity in the field? A meta-analysis. Irrigation Science, 27, 183-190. https://doi.org/10.1007/s00271-008-0141-0 
Selles, G., Ferreyra, R., Contreras, G., Ahumada, R., Valenzuelas, J., \& Bravo, R. (2004). Effect of three irrigation frequencies applied by drip irrigation over table grapes (Vitis vinifera $\mathrm{L}$. cv. Thompson Seedless) located in the Aconcagua Valley (Chile). Acta Horticulturae, 646, 175-181. https://doi.org/10.17660/ ActaHortic.2004.646.22

Shellie, K. C. (2006). Vine and berry response of Merlot (Vitis vinifera L.) to differential water stress. American Journal of Enology and Viticulture, 57, 514-518.

Shellie, K. C. (2014). Water productivity, yield, and berry composition in sustained versus regulated deficit irrigation of Merlot grapevines. American Journal of Enology and Viticulture, 65, 197-205. https://doi.org/ 10.5344/ajev.2014.13112

Shellie, K. C., \& King, B. A. (2013). Kaolin particle film and water deficit influence Malbec leaf and berry temperature, pigments, and photosynthesis. American Journal of Enology and Viticulture, 64, 223-230. https://doi.org/10.5344/ajev.2012.12115

Sinai, G., Zur, B., \& Haramati, A. (2007). Estimations of permissible irrigation rates from soil properties in high frequency irrigation. Irrigation Science, 25, 313-323. https://doi.org/10.1007/s00271-006-0044-x

Stoll, M., Loveys, B., \& Dry, P. (2000). Hormonal changes induced by partial rootzone drying of irrigated grapevine. Journal of Experimental Botany, 51, 1627-1634. https://doi.org/10.1093/jexbot/51.350.1627

Puértolas, J., Alcobendas, R., Alarcón, J. J., \& Dodd, I. C. (2013). Long-distance abscisic acid signaling under different vertical soil moisture gradients depends on bulk root water potential and average soil water content in the root zone. Plant, Cell \& Environment, 36, 1465-1475. https://doi.org/10.1111/pce.12076

\section{Copyrights}

Copyright for this article is retained by the author(s), with first publication rights granted to the journal.

This is an open-access article distributed under the terms and conditions of the Creative Commons Attribution license (http://creativecommons.org/licenses/by/4.0/). 